\title{
SEMA3E wt Allele
}

National Cancer Institute

\section{Source}

National Cancer Institute. SEMA3E wt Allele. NCI Thesaurus. Code C52932.

Human SEMA3E wild type allele is located in the vicinity of 7q21.11 and is approximately $285 \mathrm{~kb}$ in length. This allele, which encodes semaphorin-3E protein, plays a role in the mediation of both axonal guidance and vascular patterning. 